\title{
Changes in Air Quality during the COVID-19 Lockdown in Singapore and Associations with Human Mobility Trends
}

\author{
Jiayu Li*, Federico Tartarini \\ Berkeley Education Alliance for Research in Singapore, 138602, Singapore
}

\begin{abstract}
On the $7^{\text {th }}$ of April, the Singaporean government enforced strict lockdown measures with the aim of reducing the transmission chain of the coronavirus disease 2019. This had a significant impact on the movement of people within the country. Our study aims to quantify the impact that these measures had on outdoor air pollution levels. We obtained air quality and weather data from April 2016 to May 2020, satellite data for 2019 and 2020 and mobility data for 2020 from Apple, Google, and the Singaporean Housing \& Development Board. We determined that outdoor air pollution during the lockdown significantly decreased when compared with the same period in the previous four years even if we included corrections for long time trends in the analysis. The concentrations of the following pollutants $\mathrm{PM}_{10}, \mathrm{PM}_{2.5}, \mathrm{NO}_{2}, \mathrm{CO}$, and $\mathrm{SO}_{2}$ decreased by $23,29,54,6$, and $52 \%$, respectively, whilst that of $\mathrm{O}_{3}$ increased by $18 \%$. The Pollutant Standard Index decreased by $19 \%$. The trends of $\mathrm{PM}_{2.5}$ and $\mathrm{NO}_{2}$ were significantly correlated with mobility data. The $\mathrm{NO}_{2}$ and $\mathrm{SO}_{2}$ tropospheric concentrations and the total aerosol optical depth at $550 \mathrm{~nm}$ obtained from satellite data during the lockdown in 2020 were also lower than during the same period in 2019. Our results can be used to evaluate possible mitigation strategies for outdoor air quality in a longer term beyond this lockdown.
\end{abstract}

Keywords: Air pollutant; Anthropogenic pollution; Circuit breaker; SARS-CoV-2.

\section{INTRODUCTION}

On the $23^{\text {rd }}$ January 2020, Ministry of Health of Singapore confirmed the first imported case of coronavirus disease 2019 (COVID-19) caused by the infection of severe acute respiratory syndrome coronavirus 2 (SARS-CoV-2) (Ministry of Health, 2020a; Wong et al., 2020). On the $7^{\text {th }}$ of February 2020, the Singaporean government raised the Disease Outbreak Response System Condition (DORSCON) to Orange, slowly implementing measures to limit social gatherings and on the $23^{\text {rd }}$ of March banned all short-term visitors from entering the country. However, due to the increasing rate of transmission of SARS-CoV-2 in the community, as shown in Fig. $\mathrm{S} 1$ in the Appendix, on the $7^{\text {th }}$ of April 2020 Singapore implemented strict safe distancing measures (Ministry of Health, 2020b; Pung et al., 2020). The Singaporean government named these measures "CircuitBreaker", however effectively were analogous to what other Countries referred as "lockdown" or "shutdown" measures. In this paper we, therefore, decided to use the term "lockdown"

\footnotetext{
* Corresponding author.

Tel.: 65-85251223

E-mail address: jiayu.li@berkeley.edu; jiayuliaq@gmail.com
}

to describe these measures. During the lockdown period schools were closed, all workers working in non-essential sectors were imposed to work from home, and shops were closed with the exclusion of those providing essential services to the community (Lim et al., 2020; Ng, 2020). People were allowed to exit their home only for purchasing essential products or exercising, no social gatherings were allowed. These measures confined the population at home and reduced the vehicular traffic on the roads and emissions from industrial activities which in turn may had affected the concentration of anthropogenic pollutants in the outdoor air (Dutheil et al., 2020; Filonchyk et al., 2020; Le et al., 2020; Muhammad et al., 2020; Safarian et al., 2020; Xu et al., 2020). Lockdown measures in Singapore were implemented on the $7^{\text {th }}$ of April 2020 and started to progressively ease on the $12^{\text {th }}$ of May 2020 (Ministry of Health, 2020c). Hence, we labeled these 35 days from $7^{\text {th }}$ April to $11^{\text {th }}$ May 2020 as the lockdown period in this study.

Although the lockdown measures are designed to protect people from the disease, these measures have a severe impact on the economy and people's daily lives. A silver lining under this scenario may come in the form of health benefits resulting from the reduction of air pollution (Lal et al., 2020). The World Health Organization (WHO) defines outdoor air pollution as a major environmental risk to health, which negatively affects cardiovascular and respiratory health. The WHO classifies particulate matter with diameters less 
or equals to 10 micrometers $\left(\mathrm{PM}_{10}\right)$ and 2.5 micrometers $\left(\mathrm{PM}_{2.5}\right)$, nitrogen dioxide $\left(\mathrm{NO}_{2}\right)$, sulfur dioxide $\left(\mathrm{SO}_{2}\right)$ and ozone $\left(\mathrm{O}_{3}\right)$ as the major outdoor air pollutants (WHO, 2006). In Singapore the main sources of outdoor pollutants are industries and motor vehicles (National Environment Agency, 2020a). Sporadic elevated haze pollution from neighboring countries during the monsoon seasons (Velasco and Rastan, 2015) or caused by El Niño (Atwood et al., 2013) also have an impact on outdoor air quality. In Europe a report (Myllyvirta, 2020) estimated that the lockdown measures have avoided 11,000 pollution-related deaths in April 2020. The avoided $\mathrm{NO}_{2}$ and $\mathrm{PM}_{2.5}$ related deaths in China due to the cleaner air were estimated as 8911 and 3214, respectively (Chen et al., 2020a). The reduction of air pollutant has the potential to decrease the mortality rate of COVID-19 (Brandt et al., 2020; Fattorini and Regoli, 2020; Ogen, 2020) and mitigate the spread of the virus (Jiang et al., 2020; Pani et al., 2020; Sciomer et al., 2020; Yao et al., 2020).

Our aim is to quantify the change in outdoor pollutants concentrations during the lockdown period in Singapore and to evaluate their associations with mobility trends. This would allow us to better understand how anthropogenic activities and various sources in Singapore affect the overall air quality.

\section{METHODS}

\section{Air Quality Data}

The National Environment Agency (NEA) in Singapore provides Application Programming Interfaces (API)s for real-time weather readings and air quality data. The weather data APIs provide 1-minute intervals data of temperature, relative humidity, precipitations and wind conditions for a total of 64 weather stations across Singapore (National Environment Agency, 2020b).

Data on pollutants were obtained from five monitoring stations distributed strategically throughout Singapore (National Environment Agency, 2020c). The Singaporean government refers to these stations as Central $\left(1^{\circ} 21^{\prime} \mathrm{N}\right.$ $\left.103^{\circ} 49^{\prime} \mathrm{E}\right)$, East $\left(1^{\circ} 21^{\prime} \mathrm{N} 103^{\circ} 56^{\prime} \mathrm{E}\right)$, West $\left(1^{\circ} 21^{\prime} \mathrm{N} 103^{\circ} 42^{\prime} \mathrm{E}\right)$, South $\left(1^{\circ} 18^{\prime} \mathrm{N}, 103^{\circ} 49^{\prime} \mathrm{E}\right)$, and North $\left(1^{\circ} 25^{\prime} \mathrm{N}, 103^{\circ} 49^{\prime} \mathrm{E}\right)$ according to their locations in Singapore, and the national level is calculated as the main value among these five stations. We obtained outdoor air quality data from April 2016 and May 2020 using Python. The NEA releases on an hourly basis data regarding pollutants mass concentrations for: 24-h mean $\mathrm{PM}_{10}$ and $\mathrm{PM}_{2.5}$, 1-h mean $\mathrm{NO}_{2}, 8$-h mean $\mathrm{CO}, 24-\mathrm{h}$ mean $\mathrm{SO}_{2}$, and 8-h mean $\mathrm{O}_{3}$ and their relative subindices for each of the above-mentioned stations. In addition, it provides data on the 24-h Pollutant Standard Index (PSI). The NEA calculates the 24-h PSI value firstly by linearly mapping each individual sub-pollutant (i.e., 24-h $\mathrm{PM}_{10}$, 24-h $\mathrm{PM}_{2.5}$, 8-h CO, 24-h $\mathrm{SO}_{2}, 1-\mathrm{h} \mathrm{NO} \mathrm{NO}_{2}, 8-\mathrm{h} \mathrm{O}_{3}$ ) to a sub-index ranging from 0 to 500 . Then the overall 24-h PSI value is assumed to be equal to the maximum value of any of the pollutants sub-indices (National Environment Agency, 2014). More information regarding the accuracy of the instrumentation used by NEA and the location of the stations can be found on the NEA website (MSS, 2018, p. Annex 3; National Environment Agency, 2020d).

To better analyze the spatial temporal variations of $\mathrm{NO}_{2}$ and $\mathrm{SO}_{2}$ concentrations in Singapore during the lockdown period, we obtained data from the European Space Agency (ESA) Sentinel-5P TROPOMI satellite (European Space Agency, 2020). We also obtained the total aerosol optical depth (AOD) at $550 \mathrm{~nm}$ data from the Copernicus Atmosphere Monitoring Service (CAMS) (Benedetti et al., 2009; Huijnen et al., 2016; Morcrette et al., 2009). Data were processed and plotted using the Earth Engine Data Catalog (Gorelick et al., 2017). The spatial resolution of the Sentinel-5P TROPOMI satellite is 7 by $7 \mathrm{~km}^{2}$ and the satellite scans the earth with a daily revisit frequency. However, for same specific days date were either not available or may have been filtered out due to the presence of clouds. Consequently, since we plotted the average data collected over a relative short period of time, from the $7^{\text {th }}$ of April to the $11^{\text {th }}$ of May, the mean concentration calculated for some areas may not be accurate due to missing data (Kramer, 2002).

\section{Mobility Data}

We use the datasets from both Apple and Google to analyze how changes in mobility affected the air quality. Both datasets show a relative trend of how people movements changed within Singapore each day due to the impact of the COVID-19 pandemic. Google's dataset is built from data collected from users who allowed Google to access their location information. Google's data are classified into the following macro categories: workplaces, residential, retail \& recreation, grocery \& pharmacy, transit stations, and parks (Google LLC, 2020). Google uses as baseline the median value for the corresponding day of the week during the period from the $3^{\text {rd }}$ of Jan to the $6^{\text {th }}$ of Feb 2020. The data reflects how the lockdown impacted each category. The data in Apple's dataset is based on the direction requested by the users in Apple Maps, and classified into three categories: driving, public transit, and walking (Apple Inc., 2020). From both datasets, we selected the mobility parameters which have the potential to impact air quality. The selected parameters are workplaces, residential, and transport station in Google's dataset and the data of driving and public transit in Apple's dataset.

In addition to the smartphone data we acquired data regarding the Housing and Development Board (HDB) carpark availability using the API provided by the Singaporean Government (HDB, 2020). Approximately $81 \%$ of the whole population in Singapore lives in HDB apartments (HDB, 2018; Li et al., 2020), hence this data provides a meaningful estimation of how many Singaporean used their personal vehicle during the lockdown period. We gathered aggregate data on an hourly basis regarding the total number of residential occupied and free car spots across the whole country. We used this information to estimate at any point in time the percentage of people who commuted from and to their houses using a vehicle. From those data we could not infer how many cars were on the streets, since we only knew when the car left the residential parking and when it returned in the evening. 


\section{Data Analysis}

To estimate the influence of the lockdown on the outdoor air pollutants concentrations, we firstly had to estimate the concentrations without COVID-19 measures. We call this the counterfactual concentrations. For each parameter at each location, we linearly regressed the data collected over the previous four years $(2016,2017,2018$, and 2019) during the period from the $7^{\text {th }}$ April to the $11^{\text {th }}$ of May to test whether there was a consistent change of pollutants concentrations over the years. We used two methods to estimate the counterfactual value for 2020 . If the $p$-value of the linear regression is lower than 0.01 we used the value estimated by the linear regression; alternatively, we used the mean value of the last four years. The reduction was defined as the change from the counterfactual value to the measured one during the lockdown.

We have listed below the reasons why we chose to compare the outdoor concentrations to those measured in the same period of the last four years, instead of using the methodology proposed by (Kerimray et al., 2020; Otmani et al., 2020) who compared the lockdown data to a period of time in 2020 preceding the lockdown.

Firstly, we observed that the difference of meteorological parameters in the same period over different years is much smaller than the variation between two consecutive periods before and after the lockdown due to seasonal trends, as shown in Figs. S2-S5 in Appendix. The total rainfall in April is significantly higher than the rainfall in March, as shown in Fig. S4 in Appendix. Meteorological monthly or seasonal trends affect significantly some air pollutants in Singapore within each year. Hence, the difference between the lockdown period and the period of time preceding it could be inherently different and not related to the COVID-19 pandemic. On the contrary, the difference of the air pollutant between the same period in different years are much smaller.

Secondly, after the first confirmed cases in Singapore on 23 January, Singaporean government started to implement measures to contain the local transmission of the virus, such as raising the DORSCON level to orange (7 February) and an advisory about encouraging people work by telecommuting from home. These early measures may have impacted the air quality in Singapore even before the lockdown. Hence, air quality during a period before the lockdown is not suitable to serve as the baseline.

We used the Wilcoxon signed-rank test to compare the difference of the parameter during between different periods. We performed Spearman's rank correlation to access the correlation between air quality and mobility. We analyzed the data in the $\mathrm{R}$ programming language. We processed and transformed the data with data, table, lubridate, and magrittr packages and visualized them with ggplot 2 and patchwork packages. We have published the data sets and source codes we used on a public GitHub repository (https://github.com/ JiayuLIAQ/COVID-19_vs_air_quality_weather/), to allow other researchers to reproduce a similar analysis in other cities or countries.

\section{RESULTS}

The meteorological parameters in Singapore during the period between the $07^{\text {th }}$ of April and the $11^{\text {th }}$ of May from 2016 to 2020 are summarized in Table 1. During the lockdown period in 2020, temperature, relative humidity, rainfall, and wind direction were not significantly different from those recorded during the same period in previous years. Wind speed during the lockdown period was significantly higher than the previous years. However, while the difference was statistically significant, it only increased by $0.8 \mathrm{~m} \mathrm{~s}^{-1}$. More detailed comparisons can be found in Figs. S2-S5 in the Appendix.

\section{The Reduction of Air Pollutant Due to COVID-19 Lockdown}

The national level of daily PSI and mass concentrations of $\mathrm{PM}_{10}, \mathrm{PM}_{2.5}, \mathrm{NO}_{2}, \mathrm{CO}, \mathrm{SO}_{2}$, and $\mathrm{O}_{3}$ measured from 07 April and 11 May for five consecutive years (2016-2020) are plotted using boxplots in Fig. 1. The filled boxes are the interquartile ranges (IQR) for the air quality values in each year. The horizontal line in the box is the median, and the rhombus dot is the arithmetic mean. Whiskers of the boxes start from the upper and lower limits of the box and end at the length of 1.5 times the IQR or at the maximum and minimum values whichever is reached first.

During the lockdown period, the PSI was always lower than 50, which is classified by the NEA as "Good" on a 5point scale with the following categories "Good (PSI: 050)", "Moderate (PSI: 51-100)", "Unhealthy (PSI: 101-200)", "Very Unhealthy (PSI: 201-300)" and "Hazardous (PSI: above 300)". All air pollutant levels during the lockdown period were below the Singapore Targets by 2020 (National Environment Agency, 2011) which are listed in the Table S1 in Appendix. On the other hand, the PSI for the same period of last four years were higher than 50 ("Moderate") for more than $65 \%$ of the time. All the air quality parameters in 2020

Table 1. Mean and standard deviation (SD, in parentheses) of the meteorological parameter from $7^{\text {th }}$ of April to $11^{\text {th }}$ of May in 2020, 2019, and 2016-2019 overall.

\begin{tabular}{|c|c|c|c|}
\hline Parameters & 2020 & 2019 & 2016-2019 \\
\hline Temperature $\left({ }^{\circ} \mathrm{C}\right)$ & $28.7(0.9)$ & $28.9(0.9)^{\mathrm{NS}}$ & $28.3(0.9)^{\mathrm{NS}}$ \\
\hline Relative humidity (\%) & $79.7(5.5)$ & $78.7(4.5)^{\mathrm{NS}}$ & $80.6(4.4)^{\mathrm{NS}}$ \\
\hline Daily rainfall (mm) & $8.2(10.8)$ & $7.4(12.1)^{\mathrm{NS}}$ & $6.3(9.2)^{\mathrm{NS}}$ \\
\hline Wind direction $\left({ }^{\circ}\right)$ & $145.2(53.9)$ & $167.0(54.9)^{\mathrm{NS} .}$ & $162.4(48.6)^{\mathrm{NS} .}$ \\
\hline Windspeed $\left(\mathrm{m} \mathrm{s}^{-1}\right)$ & $4.7(0.5)$ & $3.9(0.6)^{* * *}$ & $4.2(0.9)^{* * *}$ \\
\hline
\end{tabular}

${ }^{* * *}$ and ${ }^{\text {NS. }}$ denote that the difference between the noted value and the corresponding value in 2020 are with high and no significance, respectively. 

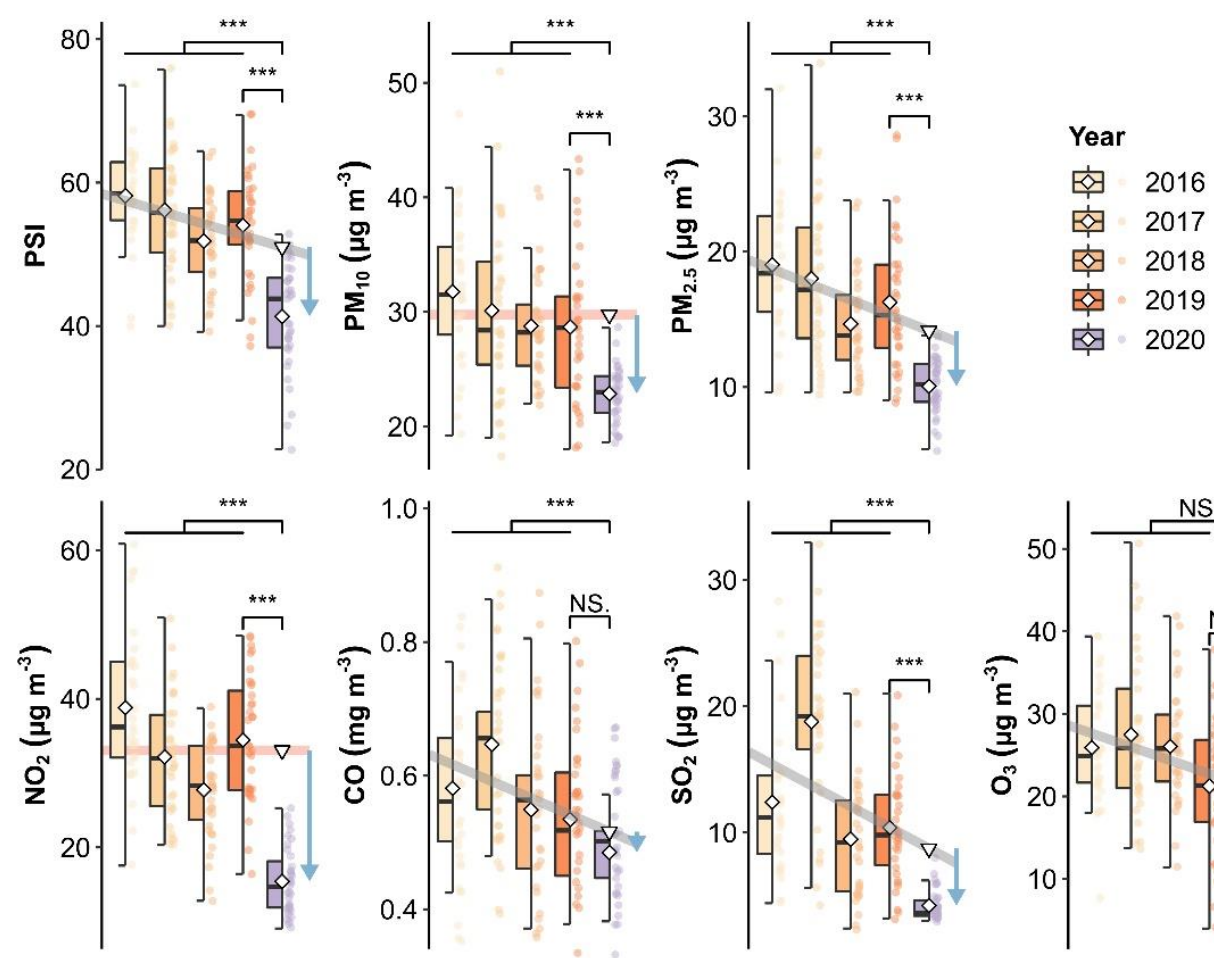

Fig. 1. National air quality parameters for the period starting on the $7^{\text {th }}$ of April and ending on the $11^{\text {th }}$ of May, from 2016 to 2020 . NS. ${ }^{*},{ }^{* *}$, and ${ }^{* * *}$ denote the difference between two samples is at the level of no (Wilcoxon $\left.p \geq 0.05\right)$, low $(0.01 \leq p$ $<0.05)$, medium $(0.001 \leq p<0.01)$, and high $(p<0.001)$ significances, respectively. The inverted triangle is the counterfactual concentration.

during the lockdown period were significantly lower than those in the previous years, with the exception of $\mathrm{O}_{3}$. Fig. 1 shows that some of the air quality variables (PSI, $\mathrm{PM}_{2.5}, \mathrm{CO}$, $\mathrm{SO}_{2}$, and $\left.\mathrm{O}_{3}\right)$ improved over the years, others not $\left(\mathrm{PM}_{10}\right.$ and $\mathrm{NO}_{2}$ ). We used semi-transparent grey lines to depict those values with significantly decreased over the last 4 years (i.e., PSI, $\mathrm{PM}_{2.5}, \mathrm{CO}, \mathrm{SO}_{2}$, and $\mathrm{O}_{3}$ ) in Fig. 1. For these parameters, predicted values in the year 2020 are used as the counterfactual concentration and marked as inverted triangles in Fig. 1. We then calculated the reduction by subtracting the average value measured this year from the counterfactual value. We showed these differences as blue arrows in Fig. 1, and summarized the results into Table 2.

During the lockdown period the national PSI decreased by $19 \%$ compared to the predicted value for 2020 , which suggests that the lockdown due to the COVID-19 pandemic had a positive impact on the reduction of the overall PSI value. The reduction of $29 \%$ in the southern area of Singapore was the highest, and 17\% in the west and north was the lowest. $\mathrm{PM}_{2.5}$ dominated PSI in Singapore, which had the third-highest reduction of $29 \%$ nationally. The $\mathrm{PM}_{2.5}$ level decreased by nearly a half in the southern area, which was the highest reduction among the five stations. $\mathrm{NO}_{2}$ and $\mathrm{SO}_{2}$ had the highest and second-highest reduction regarding percentage change rates, which decreased by $54 \%$ and $52 \%$ nationally in this year, respectively. The change in $\mathrm{PM}_{10}, \mathrm{CO}$, and $\mathrm{O}_{3}$ concentrations were relatively low when compared to other pollutants. Also, their concentration variations were not consistent among the various locations.
Though $\mathrm{PM}_{10}$ and $\mathrm{CO}$ were decreasing this year nationally in general, we observed an increase in concentrations for some of the locations. In particular, we observed a nationwide increase of $\mathrm{O}_{3}$ during the lockdown period, except for the western area. Similarly, increased $\mathrm{O}_{3}$ concentrations were observed during the lockdown period in several cities around world (Chen et al., 2020b; Collivignarelli et al., 2020; Dantas et al., 2020; Kerimray et al., 2020), which may be explained by a significant reduction of $\mathrm{NO}_{2}$ concentrations (Sicard et al., 2020).

The different reduction rates among locations could be caused by the spatial distribution of the different pollution sources in Singapore. All the heavy industries, refineries and the harbor in Singapore are located in the south-west part of the island. Singapore is one of biggest harbor in the world. To better understand the spatial variations of outdoor pollutants in the outdoor air we obtained data from the ESA Copernicus Sentinel 5P satellite. Fig. 2 shows the mean value of the $\mathrm{NO}_{2}$ and $\mathrm{SO}_{2}$ tropospheric column over Singapore. Satellite images show similar trends to those observed by ground stations and the biggest reductions of $\mathrm{NO}_{2}$ concentrations were observed in the south and west regions of the island. The biggest reductions of $\mathrm{SO}_{2}$ concentrations where observed over the island of Pulau Bukom which is an oil and petrochemicals site with manufacturing facilities for fuels, lubricant base oils and specialty chemicals. These results would, therefore, suggest that the COVID-19 and related and concurrent oil crisis may have led to a reduction of petrochemical activities in Singapore. From Fig. 2, it can 
Table 2. The change of air quality parameters during the COVID-19 pandemic at national level and at five different locations in Singapore.

\begin{tabular}{|c|c|c|c|c|c|c|c|c|c|}
\hline \multirow{2}{*}{ Parameter } & \multicolumn{3}{|c|}{ National } & \multicolumn{3}{|c|}{ Central } & \multicolumn{3}{|c|}{ East } \\
\hline & Baseline & Lockdown & $\Delta \%$ & Baseline & Lockdown & $\Delta \%$ & Baseline & Lockdown & $\Delta \%$ \\
\hline PSI & $51 \|$ & 41.3 & -19 & $54.9^{* * *}$ & 43.7 & -20 & $53.1^{* * *}$ & 42.6 & -20 \\
\hline $\mathrm{PM}_{10}\left(\mu \mathrm{g} \mathrm{m}^{-3}\right)$ & $29.8^{* * *}$ & 23 & -23 & $28.1^{* * *}$ & 23.4 & -17 & $32.5^{\|}$ & 25.5 & -21 \\
\hline $\mathrm{PM}_{2.5}\left(\mu \mathrm{g} \mathrm{m}^{-3}\right)$ & $14.4^{\|}$ & 10.1 & -30 & $16.8^{* * *}$ & 11 & -34 & $15.7^{* * * *}$ & 10.4 & -34 \\
\hline $\mathrm{NO}_{2}\left(\mu \mathrm{g} \mathrm{m}^{-3}\right)$ & $33.1^{* * *}$ & 15.1 & -54 & $27.7^{\|}$ & 14.4 & -48 & $27.8^{* * *}$ & 14 & -50 \\
\hline $\mathrm{CO}\left(\mathrm{mg} \mathrm{m}^{-3}\right)$ & $0.5^{\|}$ & 0.5 & -6 & $0.4^{\|}$ & 0.4 & -9 & $0.5^{* * *}$ & 0.6 & 35 \\
\hline $\mathrm{SO}_{2}\left(\mu \mathrm{g} \mathrm{m}^{-3}\right)$ & $8.7^{\|}$ & 4.2 & -52 & $6.1^{\|}$ & 3.6 & -41 & $11.4^{* * *}$ & 2.9 & -74 \\
\hline $\mathrm{O}_{3}\left(\mu \mathrm{g} \mathrm{m}^{-3}\right)$ & $21.1^{\|}$ & 24.9 & 18 & $25.5^{* *}$ & 30 & 17 & $23.4^{\mathrm{NS}}$ & 23.7 & 1 \\
\hline \multirow{2}{*}{ Parameter } & \multicolumn{3}{|c|}{ West } & \multicolumn{3}{|c|}{ South } & \multicolumn{3}{|c|}{ North } \\
\hline & Baseline & Lockdown & $\Delta \%$ & Baseline & Lockdown & $\Delta \%$ & Baseline & Lockdown & $\Delta \%$ \\
\hline PSI & $46.6 \|$ & 38.6 & -17 & $57.3^{* * *}$ & 40.5 & -29 & $50.7 \|$ & 42 & -17 \\
\hline $\mathrm{PM}_{10}\left(\mu \mathrm{g} \mathrm{m}^{-3}\right)$ & $22.6 \|$ & 22.9 & 1 & $34.1^{* * *}$ & 21.5 & -37 & $19.2^{\|}$ & 21.5 & 12 \\
\hline $\mathrm{PM}_{2.5}\left(\mu \mathrm{g} \mathrm{m}^{-3}\right)$ & $12.3^{\|}$ & 9.2 & -25 & $18.3^{* * *}$ & 9.8 & -46 & $13.9 \|$ & 10.2 & -27 \\
\hline $\mathrm{NO}_{2}\left(\mu \mathrm{g} \mathrm{m}^{-3}\right)$ & $22.9 \|$ & 15.2 & -33 & $31.6^{* * *}$ & 18.9 & -40 & $33.7^{* * *}$ & 14.1 & -58 \\
\hline $\mathrm{CO}\left(\mathrm{mg} \mathrm{m}^{-3}\right)$ & $0.6^{* * *}$ & 0.5 & -18 & $0.5^{*}$ & 0.5 & -13 & $0.6 \|$ & 0.4 & -26 \\
\hline $\mathrm{SO}_{2}\left(\mu \mathrm{g} \mathrm{m}^{-3}\right)$ & $15.4^{* * *}$ & 7.1 & -54 & $10.1^{\|}$ & 5.3 & -48 & $8.7^{\text {*** }}$ & 2.2 & -74 \\
\hline $\mathrm{O}_{3}\left(\mu \mathrm{g} \mathrm{m}^{-3}\right)$ & $25.7^{* * *}$ & 15.9 & -38 & $13.9^{\|}$ & 31.9 & 129 & $20.9^{\|}$ & 23 & 10 \\
\hline
\end{tabular}

"denotes that the predicted value in 2020 , i.e., the counterfactual concentration, was used for the baseline. Otherwise, the mean value of same period of last four years was used for the baseline, and star signs are given according to $p$ values $(*: 0.01 \leq p<0.05$, low significance; $* *: 0.001 \leq p<0.01$, medium significance; $* * *: p<0.001$, high significance) after Wilcoxon signed-rank tests with the value in this year during the lockdown.

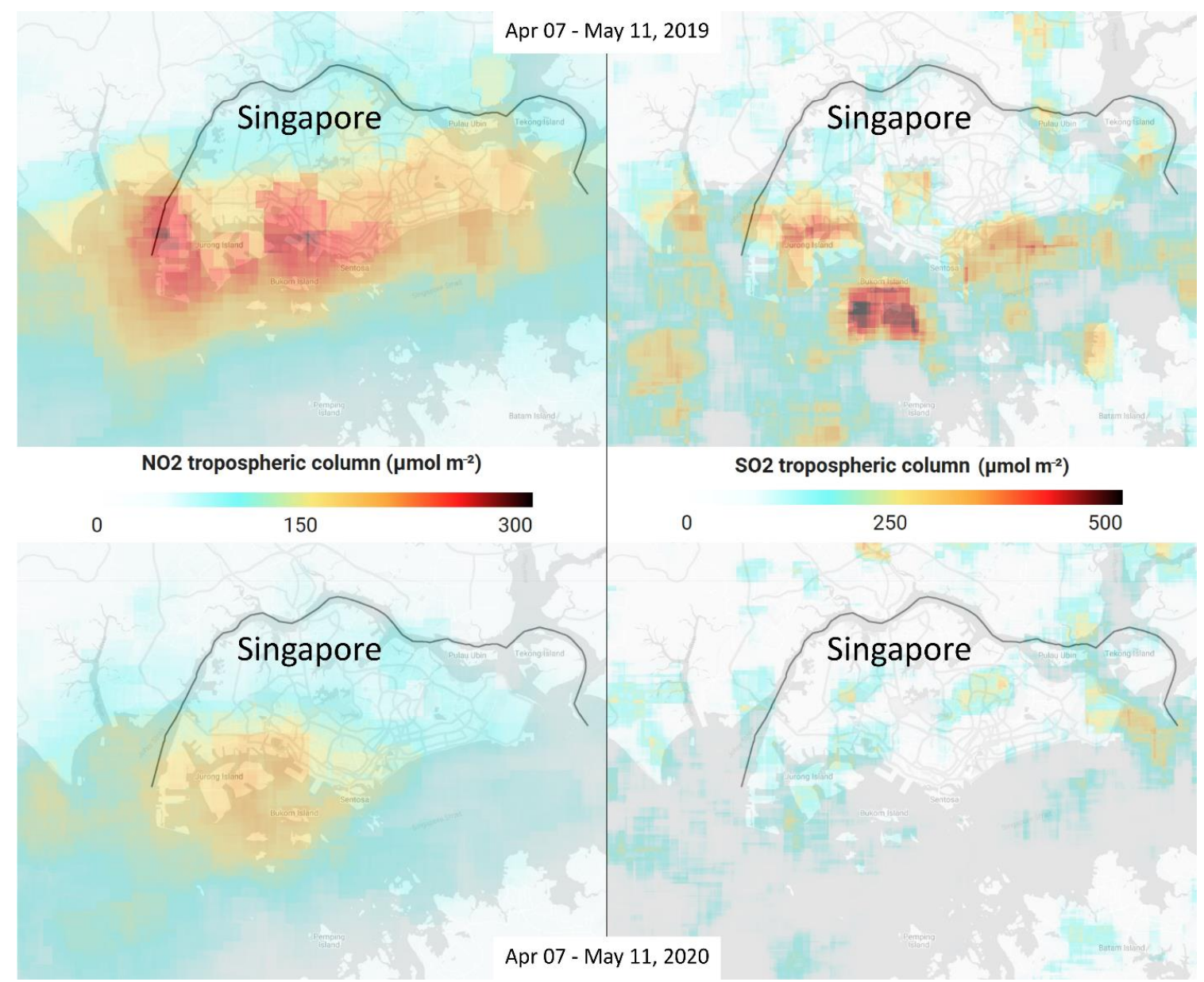

Fig. 2. Shows the mean tropospheric column concentrations of $\mathrm{NO}_{2}$ (left side) and $\mathrm{SO}_{2}$ (right side) from $7^{\text {th }}$ of $\mathrm{April}$ and $11^{\text {th }}$ of May 2019 (top side) and 2020 (bottom side). Data were obtained from the ESA Copernicus Sentinel 5P satellite. 
also be observed that $\mathrm{NO}_{2}$ concentrations decreased in the east side of Singapore. The reduction could be attributed to the reduced number of flights that landed and departed from Singapore's airport (located on the east side of the country) and possible due to the decrease in operation of the heavy industry in Malaysia located in Pasir Gudang (north east of Singapore).

Due to the low spatial resolution of AOD data, we could not analyze the spatial variations within Singapore, and we decided to report the data collected in the Southeast Asia region. Comparing to the same period in 2019, the total AOD at $550 \mathrm{~nm}$ in Singapore decreased significantly in 2020 during the lockdown. From Fig. 3, we observed that areas around Singapore also experienced a decrease of the AOD during this year. However, capitals of nearby countries such as Kuala Lumpur and Jakarta, showed an increase of the AOD level.

\section{Correlations between Air Quality and Mobility}

In order to better understand the relationship between outdoor air pollution and mobility data. We plotted in Fig. 4 the daily average levels of PSI, $\mathrm{PM}_{10}, \mathrm{PM}_{2.5}, \mathrm{NO}_{2}, \mathrm{CO}, \mathrm{SO}_{2}$, and $\mathrm{O}_{3}$ along with the selected mobility trends from $\mathrm{HDB}$, Apple, and Google databases.

Fig. 4 shows an immediate change in community mobility on the $07^{\text {th }}$ of April 2020 when the lockdown measures were implemented. Fewer people drove, took public transportation and went to work, while more people stayed at home. Mobility levels declined before and after the day the lockdown measures were implemented but in a much gentler way. This suggests that the measures were effective and widely adopted by the public. The daily averaged HDB car park availability decreased from $54 \%$ to $49 \%$. Over the same period, changes in outdoor pollutants concentrations were less pronounced than those observed in the mobility data. We can observe fluctuating downward trends for $\mathrm{PM}_{2.5}$, and $\mathrm{NO}_{2}$ levels during the lockdown period, while an increasing trend for $\mathrm{SO}_{2}$ levels.

To better understand the impact that the reduction in mobility observed in Fig. 3 had on the number of people commuting to and from their home using a motorized vehicle, we plotted the HDB carpark availability in 2020 in Fig. 5. The figure shows that while in January during working days between 9 and 19 up to $70 \%$ of the parking spots were available, this percentage reduced to $55 \%$ during the lockdown period.

The correlations between air quality and mobility parameters were tested via Spearman's rank test and the results are listed in Table $3 . \mathrm{PM}_{2.5}$ concentrations were significantly correlated with all the mobility trends and had the highest correlation coefficients with trends of people who visited transit stations comparing to other mobility data. The second-highest coefficient of $\mathrm{PM}_{2.5}$ was the workplace from Google database, which implies that the shutdown of some industries could contribute to the reduction of $\mathrm{PM}_{2.5}$. $\mathrm{NO}_{2}$ only significantly correlated with the mobility trends of car park availability (HDB dataset), driving (Apple dataset), and transit station (Google dataset), but did not with the workplace and residential ones. Both workplaces and traffic are among the main sources of $\mathrm{PM}_{2.5}$, but $\mathrm{NO}_{2}$ are more traffic related. For $\mathrm{SO}_{2}$, we found positive correlations with the human mobility trend in residential places but negative correlations with the other mobility trends. For $\mathrm{PM}_{10}, \mathrm{CO}$, and $\mathrm{O}_{3}$, we did not find any significant correlation with mobility data, while $\mathrm{O}_{3}$ concentrations showed a negative correlation with car park availability.

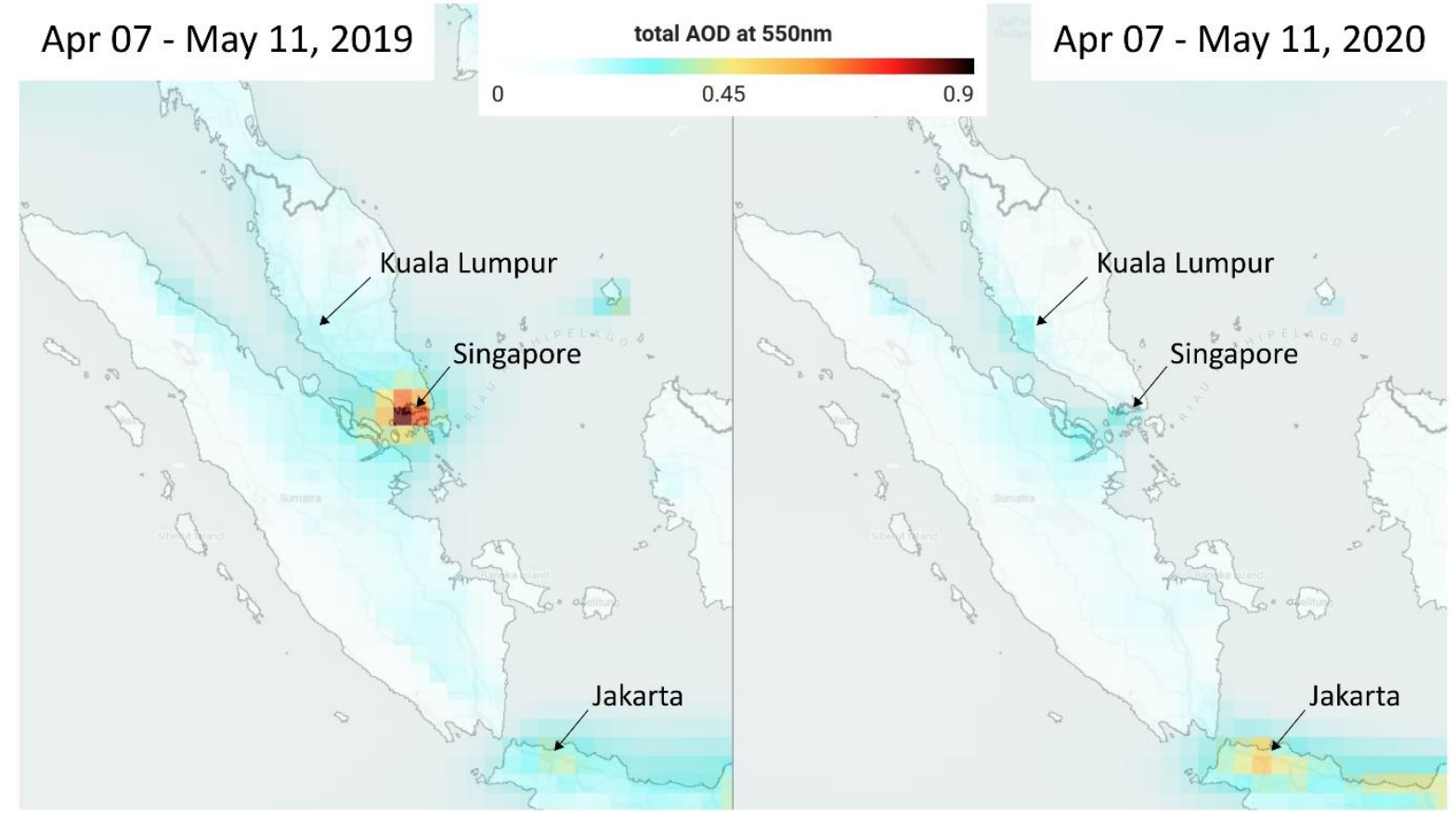

Fig. 3. Shows the mean total AOD at $550 \mathrm{~nm}$ from $7^{\text {th }}$ of April and $11^{\text {th }}$ of May 2019 (left side) and 2020 (right side). Data were obtained from the Copernicus Atmosphere Monitoring Service (CAMS). 


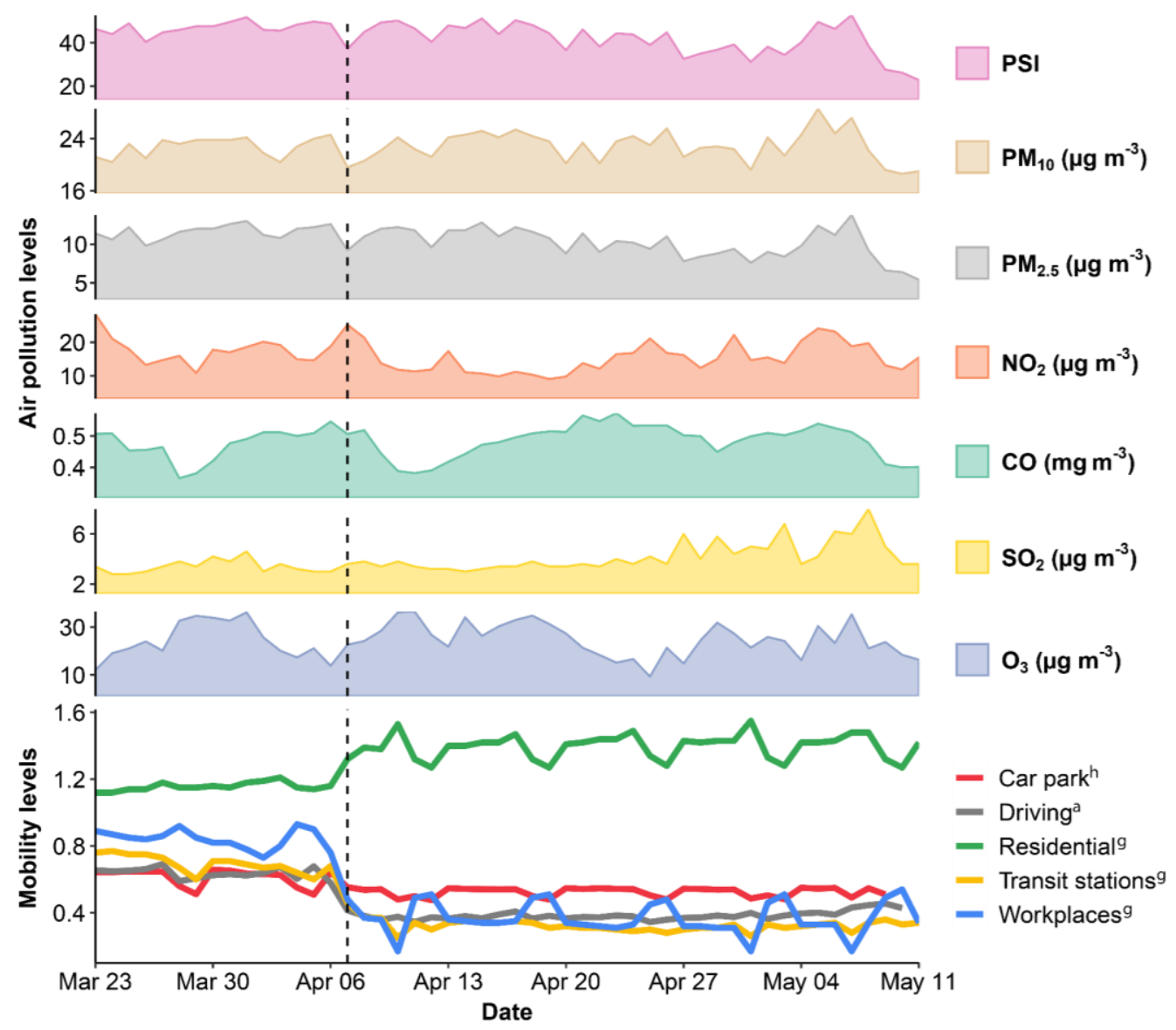

Fig. 4. Daily trends of the air quality parameter and the mobility levels since the start of earlier measures on 20 Mar 2020. h, a, and ${ }^{g}$ denote that sources of the dataset are from HDB, Apple, and Google, respectively.

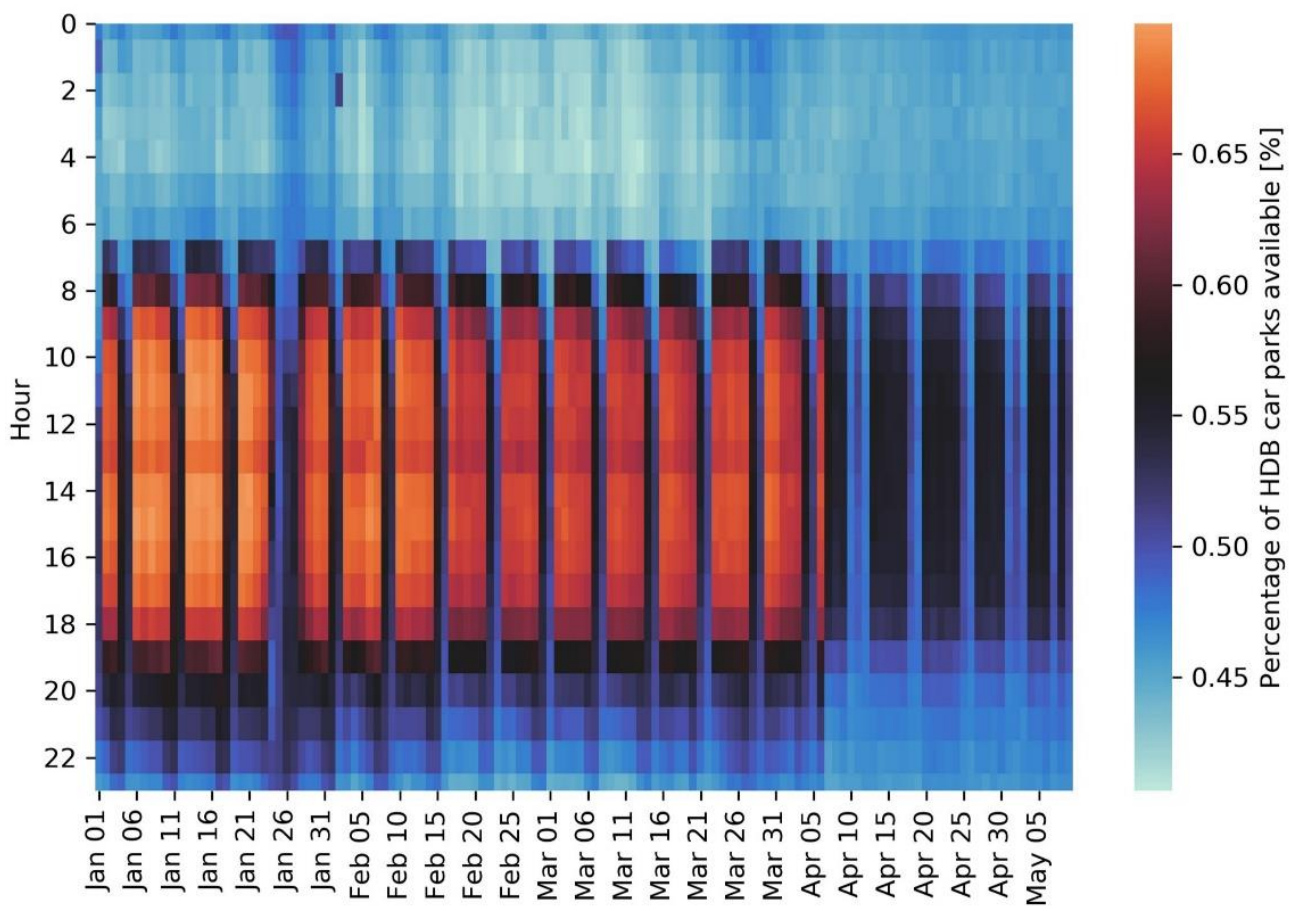

Fig. 5. HDB carpark availability prior and during the lockdown period. We centered the color bar using the percentage of car spaces available on the $7^{\text {th }}$ of April (first day of the lockdown period) at 11:00 the time of the day when generally the highest percentage of parking spots are available. 
Table 3. Spearman's rank correlation coefficients (Spearman's $\rho$ ) between air quality and mobility parameters.

\begin{tabular}{|c|c|c|c|c|c|}
\hline & Car park ${ }^{\mathrm{h}}$ & Driving $^{a}$ & Workplace $^{\mathrm{g}}$ & Transit station $^{\mathrm{g}}$ & Residential $^{\mathrm{g}}$ \\
\hline $\mathrm{PM}_{10}\left(\mu \mathrm{g} \mathrm{m}^{-3}\right)$ & $-0.03 \mathrm{NS}$. & $-0.05 \mathrm{NS}$. & $-0.07 \mathrm{NS}$ & $-0.05 \mathrm{NS}$ & 0.09 NS. \\
\hline $\mathrm{PM}_{2.5}\left(\mu \mathrm{g} \mathrm{m}^{-3}\right)$ & $0.14 *$ & $0.17 * *$ & $0.21 * * *$ & $0.28 * * *$ & $-0.19 * * *$ \\
\hline $\mathrm{NO}_{2}\left(\mu \mathrm{g} \mathrm{m}^{-3}\right)$ & $0.33 * * *$ & $0.24 * * *$ & $0.03 \mathrm{NS}$. & $0.18 * *$ & $-0.06 \mathrm{NS}$. \\
\hline $\mathrm{CO}\left(\mathrm{mg} \mathrm{m}^{-3}\right)$ & $0.07 \mathrm{NS}$. & $-0.01 \mathrm{NS}$. & $-0.08 \mathrm{NS}$. & $-0.07 \mathrm{NS}$. & 0.06 NS. \\
\hline $\mathrm{SO}_{2}\left(\mu \mathrm{g} \mathrm{m}^{-3}\right)$ & $-0.12 *$ & $-0.08 \mathrm{NS}$. & $-0.21 * * *$ & $-0.19 * * *$ & $0.22 * * *$ \\
\hline $\mathrm{O}_{3}\left(\mu \mathrm{g} \mathrm{m}^{-3}\right)$ & $-0.2 * * *$ & $-0.06 \mathrm{NS}$. & $-0.02 \mathrm{NS}$. & 0.04 NS. & $0.02 \mathrm{NS}$. \\
\hline
\end{tabular}

It is important to note that in Singapore the great majority of the population uses public transportation to commute and to move around. In 2018, in Singapore there were 957,006 registered vehicles out of which 615,452 were cars (Land Transport Authority, 2018). Consequently, less than $11 \%$ of the people living in Singapore owned a car. During the lockdown period the daily bus and train ridership decreased by more than $71 \%$ and $75 \%$, respectively. The Singaporean Transport Authority from the $15^{\text {th }}$ of April announced a that few lines were closed, however, the great majority of the bus lines, and metro trains continued to operate (Land Transport Authority, 2020). Thus, while the number of people going to work and using public transportation decreased significantly the pollution released by public transportation sector did not decrease by the same percentage.

\section{DISCUSSION}

\section{Heath Benefits of the Reduction of Air Pollutant}

Particulate matter negatively affects the health of people since it can penetrate inside the lungs and those particles with a diameter smaller than 2.5 microns can even enter the blood stream. This contributes to higher risks of developing cardiovascular, respiratory diseases and lung cancer. The World Health Organization (WHO) estimates that a reduction in the annual average concentration of particulate matter $\left(\mathrm{PM}_{2.5}\right)$ from 35 to $10 \mu \mathrm{g} \mathrm{m}^{-3}$ (WHO, 2018), reductions similar to those observed during the lockdown period, correspond to a reduction in pollution related deaths by around $15 \%$. Consequently, the reduction in outdoor pollutants during the COVID lockdown may have had a positive impact both in the short- and long-term health of Singaporeans. We observed $\mathrm{PM}_{10}$ and $\mathrm{PM}_{2.5}$ 24-h mean concentrations lower than the WHO recommended level which are $50 \mu \mathrm{g} \mathrm{m}^{-3}$ and $25 \mathrm{\mu g} \mathrm{m}^{-3}$, respectively. Moreover, the measured PM concentrations fluctuated around the recommended annual mean annual mean concentrations which are $20 \mu \mathrm{g} \mathrm{m}^{-3}$ for $\mathrm{PM}_{10}$ and $10 \mu \mathrm{g} \mathrm{m}^{-3}$ for $\mathrm{PM}_{2.5}$.

\section{Changes in Air Quality in Southeast Asia}

In southeast Asia, $\mathrm{NO}_{2}$ levels decreased by 27, 30, 22, 34, $34 \%$ in Kuala Lumpur, Singapore, Bangkok, Jakarta, Manila based on satellite images during 10 to 24 April in 2020 comparing to the average of the same period from 2015 to 2019 (Kasturi Devi Kanniah et al., 2020). The neighboring nation of Malaysia reported a national-wide drop of $\mathrm{PM}_{2.5}$ between 11.3 and $23.7 \%$ during 18 March to 14 April 2020 compared to 14 to 17 March 2020 (Abdullah et al., 2020). Suhaimi et al. (2020) showed a reduction of $\mathrm{PM}_{2.5}, \mathrm{NO}_{2}, \mathrm{CO}$, and $\mathrm{SO}_{2}$ by 3 to $36 \%, 43$ to $68 \%, 1$ to $48 \%$, and 2 to $48 \%$ according to different regions between 18 March and 21 April 2020 in Malaysia (Suhaimi et al., 2020). Nadzir et al. (2020) reported that CO concentrations decreases ranging from 40.5 to $47.5 \%$, but $\mathrm{PM}_{2.5}$ levels showed a both increase and decrease according to different regions in Malaysia during the period from 18 March to 08 April 2020 (Nadzir et al., 2020). In general, the reported reductions of air pollutants during the lockdown were comparable with the results we obtained. Compared to those studies in Southeast Asia, the reductions of $\mathrm{PM}_{2.5}, \mathrm{NO}_{2}$, and $\mathrm{SO}_{2}$ concentrations in Singapore were higher, while the reductions in $\mathrm{CO}$ were lower than in the neighboring regions, respectively.

\section{Limitation}

In Singapore outdoor pollutants concentrations vary as a function of those pollutants generated within the country and those from neighboring countries. In this study, we did not account the contribution of air pollutants from neighboring countries. The lockdown periods of Singapore and other neighboring countries were overlapped with each other, which may have had a mutual impact on the air quality of this region. Another limitation of this study was that while we gathered information on mobility from various sources, we did not have sufficient data to estimate the exact reduction of vehicular traffic on the roads. We also did not have data on how much some industrial activities (e.g., port, refineries, airport, power generation) decreased during the lockdown period. Consequently, while we observed that they play a significant role in generating harmful outdoor pollutants, we were not able to correlate a decrease in emission from industrial activities with a reduction in outdoor concentrations. Finally, while we observed a significant decrease in outdoor pollutants, it would be difficult to estimate the positive health effect on the population since the great majority of the population stayed indoor during the lockdown period and was exposed to the cleaner air only for a short period of time.

\section{CONCLUSIONS}

In this study, we used nationwide data of PSI, $\mathrm{PM}_{10}$, $\mathrm{PM}_{2.5}, \mathrm{NO}_{2}, \mathrm{CO}, \mathrm{SO}_{2}$, and $\mathrm{O}_{3}$ from 2016 to 2020 to determine how outdoor pollutants concentrations varies 
during the lockdown period (from the $7^{\text {th }}$ April to the $11^{\text {th }}$ May) in Singapore. Detailed spatial distribution characteristics of $\mathrm{NO}_{2}$ and $\mathrm{SO}_{2}$ were analyzed using data from the European Space Agency Copernicus Sentinel 5P satellite. Mobility datasets from the Singaporean Housing Development Board, Apple, and Google were used to identify the influence factors of the improvement of air quality. The main findings are listed below:

1. Nationwide, the reductions in PSI, $\mathrm{PM}_{10}, \mathrm{PM}_{2.5}, \mathrm{NO}_{2}$, $\mathrm{CO}$, and $\mathrm{SO}_{2}$ were 19, 23, 29, 54, 6, and 52\%, respectively, while $\mathrm{O}_{3}$ increased by $18 \%$.

2. The levels of PSI, $\mathrm{PM}_{2.5}, \mathrm{NO}_{2}$, and $\mathrm{SO}_{2}$ decreased during the lockdown in all the five areas of Singapore, while $\mathrm{PM}_{10}$ in the north and $\mathrm{CO}$ in the east showed opposite trends. $\mathrm{O}_{3}$ decreased only in the west but increased in the other four areas. The southern and western areas had the most substantial reduction of air pollution in Singapore, which is due to the local spatial distribution of heavy industries and the airport.

3. The levels of $\mathrm{PM}_{2.5}$ and $\mathrm{NO}_{2}$ were significantly correlated with the reduction trend of human mobility data. The reduced visits to workplaces and transit stations had the highest two correlation coefficient with $\mathrm{PM}_{2.5}$, and the reduction of traffic-related mobility data, such as, car park availability and driving, correlated with $\mathrm{NO}_{2}$.

4. The satellite data showed that the slowdown in the aviation, refining, and port activities contributed to the reduction of $\mathrm{NO}_{2}, \mathrm{SO}_{2}$ and $\mathrm{AOD}$ concentrations.

\section{ACKNOWLEDGMENTS}

This research was funded by the Republic of Singapore's National Research Foundation through a grant to the Berkeley Education Alliance for Research in Singapore (BEARS) for the Singapore-Berkeley Building Efficiency and Sustainability in the Tropics (SinBerBEST) Program. BEARS has been established by the University of California, Berkeley as a center for intellectual excellence in research and education in Singapore.

\section{DISCLAIMER}

The authors declare that they have no conflict of interest.

\section{SUPPLEMENTARY MATERIAL}

Supplementary data associated with this article can be found in the online version at https://aaqr.org/

\section{REFERENCES}

Abdullah, S., Mansor, A.A., Napi, N.N.L.M., Mansor, W.N.W., Ahmed, A.N., Ismail, M. and Ramly, Z.T.A. (2020). Air quality status during 2020 Malaysia Movement Control Order (MCO) due to 2019 novel coronavirus (2019-nCoV) pandemic. Sci. Total Environ. 729: 139022. https://doi.org/10.1016/j.scitotenv.2020.139022 Apple Inc. (2020). COVID-19 - Mobility trends reports. https://www.apple.com/covid19/mobility
Atwood, S.A., Reid, J.S., Kreidenweis, S.M., Yu, L.E., Salinas, S.V., Chew, B.N. and Balasubramanian, R. (2013). Analysis of source regions for smoke events in Singapore for the $2009 \mathrm{El}$ Nino burning season. Atmos. Environ. 78: 219-230. https://doi.org/10.1016/j.atmosenv.2013.04.047

Benedetti, A., Morcrette, J.J., Boucher, O., Dethof, A., Engelen, R.J., Fisher, M., Flentje, H., Huneeus, N., Jones, L., Kaiser, J.W., Kinne, S., Mangold, A., Razinger, M., Simmons, A.J. and Suttie, M. (2009). Aerosol analysis and forecast in the European Centre for medium-range weather forecasts integrated forecast system: 2. Data assimilation. J. Geophys. Res. 114: D13205. https://doi.org/ 10.1029/2008JD011235

Brandt, E.B., Beck, A.F. and Mersha, T.B. (2020). Air pollution, racial disparities and COVID-19 mortality. $J$. Allergy Clin. Immunol. 146: 61-63. https://doi.org/10.10 16/j.jaci.2020.04.035

Chen, K., Wang, M., Huang, C., Kinney, P.L. and Anastas, P.T. (2020a). Air pollution reduction and mortality benefit during the COVID-19 outbreak in China. Lancet Planetary Health 4: e210-e212. https://doi.org/10.1016/ S2542-5196(20)30107-8

Chen, Q.X., Huang, C.L., Yuan, Y. and Tan, H.P. (2020b). Influence of COVID-19 event on air quality and their association in Mainland China. Aerosol Air Qual. Res. 20: 1541-1551. https://doi.org/10.4209/aaqr.2020.05.0224

Collivignarelli, M.C., Abbà, A., Bertanza, G., Pedrazzani, R., Ricciardi, P. and Carnevale Miino, M. (2020). Lockdown for CoViD-2019 in Milan: What are the effects on air quality? Sci. Total Environ. 732: 139280. https://doi.org/10.1016/j.scitotenv.2020.139280

Dantas, G., Siciliano, B., França, B.B., da Silva, C.M. and Arbilla, G. (2020). The impact of COVID-19 partial lockdown on the air quality of the city of Rio de Janeiro, Brazil. Sci. Total Environ. 729: 139085. https://doi.org/ 10.1016/j.scitotenv.2020.139085

Dutheil, F., Baker, J.S. and Navel, V. (2020). COVID-19 as a factor influencing air pollution? Environ. Pollut. 263: 114466. https://doi.org/10.1016/j.envpol.2020.114466

European Space Agency (2020). Sentinel-5P TROPOMI user guide. Sentinel Online. https://sentinel.esa.int/web/ sentinel/user-guides/sentinel-5p-tropomi

Fattorini, D. and Regoli, F. (2020). Role of the chronic air pollution levels in the COVID-19 outbreak risk in Italy. Environ. Pollut. 264: 114732. https://doi.org/10.1016/j.e nvpol.2020.114732

Filonchyk, M., Hurynovich, V., Yan, H., Gusev, A. and Shpilevskaya, N. (2020). Impact assessment of COVID19 on variations of $\mathrm{SO}_{2}, \mathrm{NO}_{2}, \mathrm{CO}$ and $\mathrm{AOD}$ over East China. Aerosol Air Qual. Res. 20: 1530-1540. https://doi.org/10.4209/aaqr.2020.05.0226

Google LLC. (2020). COVID-19 community mobility report. COVID-19 Community Mobility Reports. https://www.g oogle.com/covid19/mobility

Gorelick, N., Hancher, M., Dixon, M., Ilyushchenko, S., Thau, D. and Moore, R. (2017). Google Earth Engine: Planetary-scale geospatial analysis for everyone. Remote Sens. Environ. 202: 18-27. https://doi.org/10.1016/j.rse.2 017.06.031 
Housing and Development Board (HDB) (2018). Annual Reports - Housing \& Development Board (HDB). https://www.hdb.gov.sg/cs/infoweb/about-us/news-andpublications/annual-reports

Housing and Development Board (HDB) (2020). HDB Carpark Information. Data.gov.sg. https://data.gov.sg/da taset/hdb-carpark-information

Huijnen, V., Eskes, H.J., Wagner, A., Schulz, M., Christophe, Y., Ramonet, M., Basart, S., Benedictow, A., Blechschmidt, A.M., Chabrillat, S., Clark, H., Cuevas, E., Flentje, H., Hansen, K.M., Im, U., Kapsomenakis, J., Langerock, B., Richter, A., Sudarchikova, N. and Thouret, V. (2016). Validation report of the CAMS near-real-time global atmospheric composition service: System evolution and performance statistics. Status up to 1 June 2016. https://pure.au.dk/portal/en/persons/ulas-im(e2356d828e7b-49c9-b660-76e719a4058e)/publications/validationreport-of-the-cams-nearrealtime-global-atmosphericcomposition-service-system-evolution-and-performancestatistics-status-up-to-1-june-2016(d3511b2f-b56a-4fe59400-1e469b1de93f).html

Jiang, Y., Wu, X.J. and Guan, Y.J. (2020). Effect of ambient air pollutants and meteorological variables on COVID19 incidence. Infect. Control Hosp. Epidemiol. 1-5. https://doi.org/10.1017/ice.2020.222

Kanniah, K.D., Zaman, N.A.F.K., Kaskaoutis, D.G. and M.T. (2020). COVID-19's impact on the atmospheric environment in the Southeast Asia region. Sci. Total Environ. 736: 139658. https://doi.org/10.1016/j.scitotenv. 2020.139658

Kerimray, A., Baimatova, N., Ibragimova, O.P., Bukenov, B., Kenessov, B., Plotitsyn, P. and Karaca, F. (2020). Assessing air quality changes in large cities during COVID-19 lockdowns: The impacts of traffic-free urban conditions in Almaty, Kazakhstan. Sci. Total Environ. 730: 139179. https://doi.org/10.1016/j.scitotenv.2020.139179

Kramer, H.J. (2002). Observation of the Earth and its environment: Survey of missions and sensors, SpringerVerlag, Berlin Heidelberg.

Lal, P., Kumar, A., Kumar, S., Kumari, S., Saikia, P., Dayanandan, A., Adhikari, D. and Khan, M.L. (2020). The dark cloud with a silver lining: Assessing the impact of the SARS COVID-19 pandemic on the global environment. Sci. Total Environ. 732: 139297. https://doi.org/10.1016/j.scitotenv.2020.139297

Land Transport Authority (2018). Annual Vehicle Statistics 2018.

Land Transport Authority (2020). Changes to public bus and train operating hours and frequency. https://www.lt a.gov.sg/content/ltagov/en/newsroom/2020/april/newsreleases/Changes_to_public_bus_and_train_operating_h ours.html

Le, T., Wang, Y., Liu, L., Yang, J., Yung, Y.L., Li, G. and Seinfeld, J.H. (2020). Unexpected air pollution with marked emission reductions during the COVID-19 outbreak in China. Science 2020: eabb7431 https://doi.org/10.1126/s cience.abb7431

Li, J., Wan, M.P., Schiavon, S., Tham, K.W., Sultan, Z., Xiong, J., Fang, M. and Gall, E. (2020). Size-resolved dynamics of indoor and outdoor fluorescent biological aerosol particles in a bedroom: A one-month case study in Singapore. Indoor Air https://doi.org/10.1111/ina.12678

Lim, L.W., Yip, L.W., Tay, H.W., Ang, X.L., Lee, L.K., Chin, C.F. and Yong, V. (2020). Sustainable practice of ophthalmology during COVID-19: challenges and solutions. Graefes Arch. Clin. Exp. Ophthalmol. 258: 14271436. https://doi.org/10.1007/s00417-020-04682-z

Meteorological Service Singapore (MSS) (2018). Annual climatological report 2018. http://www.weather.gov.sg/ wp-content/uploads/2019/03/Annual-Climatological-Re port-2018.pdf

Ministry of Health (2020a). Confirmed imported case of novel coronavirus infection in Singapore. https://www.moh. gov.sg/news-highlights/details/confirmed-imported-caseof-novel-coronavirus-infection-in-singapore-multi-minis try-taskforce-ramps-up-precautionary-measures

Ministry of Health (2020b). circuit breaker to minimise further spread of COVID-19. https://www.moh.gov.sg/n ews-highlights/details/circuit-breaker-to-minimise-furth er-spread-of-covid-19

Ministry of Health (2020c). Easing the tighter circuit breaker measures, preparing for gradual resumption of activity after 1 June. https://www.moh.gov.sg/newshighlights/details/easing-the-tighter-circuit-breaker-mea sures-preparing-for-gradual-resumption-of-activity-after1 -june

Morcrette, J.J., Boucher, O., Jones, L., Salmond, D., Bechtold, P., Beljaars, A., Benedetti, A., Bonet, A., Kaiser, J.W., Razinger, M., Schulz, M., Serrar, S., Simmons, A.J., Sofiev, M., Suttie, M., Tompkins, A.M. and Untch, A. (2009). Aerosol analysis and forecast in the European Centre for medium-range weather forecasts integrated forecast system: Forward modeling. J. Geophys. Res. 114: D06206. https://doi.org/10.1029/2008JD011235

Muhammad, S., Long, X. and Salman, M. (2020). COVID19 pandemic and environmental pollution: A blessing in disguise? Sci. Total Environ. 728: 138820. https://doi.org/ 10.1016/j.scitotenv.2020.138820

Myllyvirta, L. (2020). 11,000 air pollution-related deaths avoided in Europe as coal, oil consumption plummet. Centre for Research on Energy and Clean Air. https://energyandcleanair.org/air-pollution-deaths-avoid ed-in-europe-as-coal-oil-plummet/

Nadzir, M.S.M., Ooi, M.C.G., Alhasa, K.M., Bakar, M.A.A., Mohtar, A.A.A., Nor, M.F.F.M., Latif, M.T., Hamid, H.H.A., Ali, S.H.M., Ariff, N.M., Anuar, J., Ahamad, F., Azhari, A., Hanif, N.M., Subhi, M.A., Othman, M. and Nor, M.Z.M. (2020). The impact of Movement Control Order (MCO) during pandemic COVID-19 on local air quality in an urban area of Klang Valley, Malaysia. Aerosol Air Qual. Res. 20: 1237-1248. https://doi.org/10.4209/aaqr.2020.04.0163

National Environment Agency (2011). Executive summary report of the advisory committee on ambient air quality. https://www.nea.gov.sg/docs/default-source/our-services/ pollution-control/air-pollution/air-quality/executive-sum mary.pdf

National Environment Agency (2014). Computation of the 
Pollutant Standards Index (PSI). https://www.haze.gov.sg/ docs/default-source/faq/computation-of-the-pollutant-st andards-index-(psi).pdf

National Environment Agency (2020a). Air quality in Singapore. https://www.nea.gov.sg/our-services/pollutio n-control/air-pollution/air-quality

National Environment Agency (2020b). Realtime weather readings across Singapore. Data.gov.sg. https://data.gov. sg/dataset/realtime-weather-readings

National Environment Agency (2020c). Pollutant standards index. (PSI) Data.gov.sg. https://data.gov.sg/dataset/psi

National Environment Agency (2020d). The national environment agency. https://www.nea.gov.sg/index

Ng, N.M. (2020). Things you need to know about Singapore's "circuit breaker" measures. Time Singap. https://www.timeout.com/singapore/things-to-do/thingsyou-need-to-know-about-singapores-circuit-breaker-me asures

Ogen, Y. (2020). Assessing nitrogen dioxide $\left(\mathrm{NO}_{2}\right)$ levels as a contributing factor to coronavirus (COVID-19) fatality. Sci. Total Environ. 726: 138605. https://doi.org/ 10.1016/j.scitotenv.2020.138605

Otmani, A., Benchrif, A., Tahri, M., Bounakhla, M., Chakir, E.M., El Bouch, M. and Krombi, M. (2020). Impact of COVID-19 lockdown on $\mathrm{PM}_{10}, \mathrm{SO}_{2}$ and $\mathrm{NO}_{2}$ concentrations in Salé City (Morocco). Sci. Total Environ. 735: 139541. https://doi.org/10.1016/j.scitotenv.2020.13 9541

Pani, S.K., Lin, N.H. and RavindraBabu, S. (2020). Association of COVID-19 pandemic with meteorological parameters over Singapore. Sci. Total Environ. 740: 140112. https://doi.org/10.1016/j.scitotenv.2020.140112

Pung, R., Chiew, C.J., Young, B.E., Chin, S., Chen, M.I.C., Clapham, H.E., Cook, A.R., Maurer-Stroh, S., Toh, M.P.H.S., Poh, C., Low, M., Lum, J., Koh, V.T.J., Mak, T.M., Cui, L., Lin, R.V.T.P., Heng, D., Leo, P.Y.S., Lye, D.C., ... Ang, L.W. (2020). Investigation of three clusters of COVID-19 in Singapore: Implications for surveillance and response measures. Lancet 395: 1039-1046. https://doi.org/10.1016/S0140-6736(20)30528-6

Safarian, S., Unnthorsson, R. and Richter, C. (2020). Effect of coronavirus disease 2019 on $\mathrm{CO}_{2}$ emission in the world. Aerosol Air Qual. Res. 20: 1197-1203. https://doi.org/1 0.4209/aaqr.2020.04.0151
Sciomer, S., Moscucci, F., Magrì, D., Badagliacca, R., Piccirillo, G. and Agostoni, P. (2020). SARS-CoV-2 spread in Northern Italy: What about the pollution role? Environ. Monit. Assess. 192: 325. https://doi.org/10.1007/ s10661-020-08317-y

Sicard, P., De Marco, A., Agathokleous, E., Feng, Z., Xu, X., Paoletti, E., Rodriguez, J.J.D. and Calatayud, V. (2020). Amplified ozone pollution in cities during the COVID-19 lockdown. Sci. Total Environ. 735: 139542. https://doi.org/10.1016/j.scitotenv.2020.139542

Suhaimi, N.F., Jalaludin, J. and Latif, M.T. (2020). Demystifying a possible relationship between COVID19, air quality and meteorological factors: Evidence from Kuala Lumpur, Malaysia. Aerosol Air Qual. Res. 20: 1520-1529. https://doi.org/10.4209/aaqr.2020.05.0218

Velasco, E. and Rastan, S. (2015). Air quality in Singapore during the 2013 smoke-haze episode over the Strait of Malacca: Lessons learned. Sustain. Cities Soc. 17: 122131. https://doi.org/10.1016/j.scs.2015.04.006

Wong, J.E.L., Leo, Y.S. and Tan, C.C. (2020). COVID-19 in Singapore-current experience: Critical global issues that require attention and action. JAMA 323: 1243-1244. https://doi.org/10.1001/jama.2020.2467

World Health Organization (WHO) (2006). WHO Air quality guidelines for particulate matter, ozone, nitrogen dioxide and sulfur dioxide: Global update 2005: Summary of risk assessment. World Health Organization, Geneva.

World Health Organization (WHO) (2018). Ambient (outdoor) air pollution. https://www.who.int/news-room/fact-sheet s/detail/ambient-(outdoor)-air-quality-and-health

Xu, K., Cui, K., Young, L.H., Hsieh, Y.K., Wang, Y.F., Zhang, J. and Wan, S. (2020). Impact of the COVID-19 event on air quality in central China. Aerosol Air Qual. Res. 20: 915-929. https://doi.org/10.4209/aaqr.2020.04.0150

Yao, M., Zhang, L., Ma, J. and Zhou, L. (2020). On airborne transmission and control of SARS-Cov-2. Sci. Total Environ. 731: 139178. https://doi.org/10.1016/j.scitoten v. 2020.139178

Received for review, June 11, 2020

Revised, July 2, 2020

Accepted, July 16, 2020 